Article

\title{
Legitimacy and the Transfer of Children: Adoption, Belonging, and Online Genealogy
}

\author{
Sandra Patton-Imani \\ Department for the Study of Culture and Society, Drake University, Des Moines, IA 50311, USA; \\ sandra.patton-imani@drake.edu
}

Received: 8 August 2018; Accepted: 10 September 2018; Published: 20 September 2018

check for updates

\begin{abstract}
A great deal of both scholarly and public attention has been paid to questions of nature versus nurture in understanding identity and family construction in adoptees, yet much less attention has been given to the ways that power shapes the social reproduction of families through adoption. In this feminist interdisciplinary self-reflexive ethnographic research, I enter the world of online genealogy sites to critically explore the social practice of constructing a family tree as an adoptee. I explore genealogy as a culturally and historically specific representation of patriarchal heteronormative whiteness. I argue that adoptees' liminal locations between socially understood categories of nature and nurture embedded in online family heritage websites make evident the ways that genealogical templates and stories reproduce mainstream family ideology through the erasure of "illegitimacy". I consider what I found in my adoptive family history, critically exploring my "legitimate" relationship to my family in relation to the "illegitimate" (and unrecognized) relationship between my family and an enslaved child transferred as property between family members in 1813. This research makes visible power inequalities governing family reproduction at macro levels by exploring the contradictions and slippages regarding family "legitimacy" in micro level online genealogical constructions of adoptees' family trees.
\end{abstract}

Keywords: adoption; belonging; roots; genealogy; power; nature; nurture; reproductive justice; legitimacy; illegitimacy

\section{Introduction}

Shafts of afternoon light illuminated variegated shades of lavender and purple against shadows of the carpet's original dark blue on my bedroom floor. I sat there experiencing my first existential crisis. I was twelve. I was supposed to be doing my homework-making a family tree. The mix of shadow and sun evidenced time's passage in the fading colors of the quiet afternoon. I could not fill in the genealogical template I had been given. I felt trapped by the logic of nature versus nurture embedded in the question of heritage. I was experiencing what social workers often call "genealogical bewilderment" in discussions of adoption, identity, and family history. ${ }^{1} \mathrm{I}$ knew the assignment was about biological family connections. It was 1977 and talk about 'Roots' was everywhere. ${ }^{2}$ My sisters and parents, aunts, uncles, cousins, and grandparents were easy. As an adoptee I was well practiced at redefining social definitions of "natural" and "normal". I loved my parents, so that made them my family. However the ancestors that came before them were completely unknown. By what logic could I claim them as mine, or I, as theirs? I knew almost nothing of my biological family; they were only a seething absence. I did not really belong, it seemed, to either family history.

1 The term was introduced by psychologist and psychotherapist H.J. Sants in his 1964 article (Sants 1964). Betty Jean Lifton (Lifton 1988) embraced and popularized this concept in her influential 1988 book Lost and Found: The Adoption Experience.

2 Alex Haley's book Roots (Haley 1976) and the television miniseries released in 1977 sparked a renewed interest in genealogy in the U.S. 
Questions of identity, roots, and belonging are central themes in both popular and academic discourse on adoption. Adoptees' identities and family heritage are typically framed through the language of nature versus nurture, or culture versus biology in discussions of adoption at individual, familial, community, national, and transnational levels of meaning production. Adoptees are often represented as "genealogically bewildered" - without "real" family and heritage until our birth parents are found. Many people argue that searching for birth parents is the only way to learn one's "true" self. Others argue that focusing on biology or DNA as the determinant of heritage ignores the lived experiences of family and child rearing. Anthropologist Barbara Yngvesson suggests there is an inherent tension built into the structure of adoptive families that "simultaneously constitutes and disrupts a genealogical imaginary for what a 'real' family consists in" (Yngvesson 2010, p. 15). These questions are profoundly shaped by race, gender, sexuality, and class in both transracial and same-race adoptions. ${ }^{3}$ Indeed, questions of adoptees" "real" identities seem to embody these deep social tensions about the "truth" of family, heritage, and belonging. A great deal of scholarly and public attention has been paid to questions of nature versus nurture in understanding identity and family construction in adoptees, yet much less attention has been given to the ways that power shapes the social reproduction of families through adoption.

In this interdisciplinary self-reflexive ethnographic research I enter the world of online genealogy sites to critically explore the social practice of constructing a family tree as an adoptee. Exploring one's family tree online is a narration, a guided performance of family ideology scripted through the operating systems of online genealogy sites. Adoption is a historically and culturally specific social system and practice of child transfer, and the social definitions of family engaged and reproduced speak to larger assumptions about kinship and belonging in society. The social location of adoptees requires us to negotiate these meanings in particular ways and that process is useful for thinking about the ways that power relations are reproduced in everyday cultural practices. In this essay I seek to explore these questions: What does the experience of an adoptee creating a family tree tell us about the systemic construction of family and belonging in the U.S.? How is the engagement with online genealogy programs part of the way that structural power relations quietly shape social understandings of personhood, family, and social belonging — for everyone, not just adoptees?

Feminist scholarship on families makes evident that kinship is not "natural," but rather, is a socially constructed category that is organized differently in various eras and locations (Thorne and Yalom 1982). This framework challenges views of patriarchal white heteronormative definitions of family as natural and normal, making clear that power has always shaped the ways that families are organized and understood. We often think of genealogy as a neutral recorder of "natural" family ties. Genealogy is a politically and historically specific social practice that has shifted over time and space in relation to the specificities of kinship, belonging, and nation in different societies and different eras (Weil 2013). When we recognize that families are always shaped by social power, we can begin to see that genealogy too is a culturally specific practice that works in tandem with power to reproduce social definitions of natural and normal families. In the United States genealogy has historically been about the reproduction of patriarchal heteronormative whiteness through the social construction of particular family forms, and this is reflected in templates for genealogical legitimacy structuring the story and the performance of the family tree.

I argue that adoptees' liminal locations between socially understood categories of nature and nurture embedded in online family heritage websites make evident the ways that genealogical templates and stories reproduce mainstream family ideology and function to maintain systemic inequality. Genealogy programs may seem like impartial tools for documenting family relationships, but engaging with these systems requires engagement with hegemonic views of "normal" and "natural" families. These online systems

3 For in depth discussions of transracial and transnational adoption see Cox (1999, 2011); Dorow (2006); Eng (2010); Evans (2000); Haslanger and Witt (2005); Ito and Cervin (1999); Kim (2005, 2010); Nelson (2009); Oh (2012); Patton (2000); Patton-Imani (2012, 2014); Richards (2012); Trenka et al. (2006); Volkman (2005); Yngvesson (2005, 2010). 
are organized through the same sets of power relations regulating race, gender, class, sexuality, and reproduction that families are. Indeed, in my view the contemporary social practice of documenting and creating family trees functions to reproduce (white middle class heteronormative) macro definitions of legitimate kinship and belonging at the micro level of lived experience.

I draw on ethnographic methods of participant-observation to critically explore the process of creating a family tree as a person with more than one set of parents-birth and adoptive. Drawing on participant-observation in the online world of genealogy, I explore the ways the structure of online programs for creating family trees reproduces and enforces societal definitions of legitimate family. I draw on intersectional feminist research on family and reproductive justice to analyze the complex relationships between reproductive politics and the maintenance of social inequalities. ${ }^{4}$ In the final section I consider what I found in my adoptive family history, critically exploring my (legally) "legitimate" relationship to my family in relation to the "illegitimate" (and unrecognized) relationship between my family and an enslaved child transferred as property between family members in 1813 .

This article is comprised of two halves. In the first few sections, I analyze the process of exploring and creating my online family tree. In the final section, I scrutinize the redacted history I found there. The first half puts my own life in social and cultural context, considering the ways that adoption was practiced in the U.S. in the post-World War II era as a means of regulating unwed pregnancy and reproducing idealized versions of white middle class heteronormative family. In my exploration of what I found in my family tree, I consider the life of an enslaved child named Julia who was transferred as property by her owner, a man that was likely her biological father. I explore the ways that reproductive policies and practices served to support mainstream definitions of family legitimacy in each era. Each of our life stories is shaped through historically and socially specific definitions of family legitimacy that bolster images of white middle class families as sexually and racially "pure" by erasing "illegitimacy".

Critically exploring the differences and parallels of Julia's and my relationships to this family in social and historical context demonstrates the limitations of the nature versus nurture framework. While these tensions typically organize discussions of adoption and genealogy, my analysis shows that these explanatory narratives are not sufficient for understanding the ways that social ideals of gender, race, class, and sexuality are regulated in particular historical moments through laws and policies regulating family and reproduction. Power must be recognized as part of these genealogies. I engage these life stories to consider the ways that race, gender, sexuality, and class operate to regulate and maintain mainstream definitions of legitimate patriarchal families in different historical moments. My legal transfer into this family is the other side of the coin from Julia's erasure from it. It is not just nature or nurture that regulates our relationships to this family, but also, illegitimacy and power.

\section{Insider-Outsiders Everywhere}

I entered the world of online genealogy websites as a "participant," but soon became an "observer" as well. I didn't intend to begin a new research project. In fact, I was deeply immersed in writing my second book (Patton-Imani 2019). As I was beginning my sabbatical I needed a brain break and genealogy was the alternate world I entered. The tensions I first experienced as a kid trying to construct a family tree had continued to haunt me. The desire to find a place of belonging in my family fueled a continued interest in genealogy, so I began exploring and researching, and in the process, found myself crafting an online public narrative of family. It was clear from the beginning that I was an interloper. "DNA certified" was the highest accreditation available for familial relationships in this cyber-world. White middle class heteronormativity is the unspoken template for family, and the naturalization of this family structure makes the power inequalities driving it invisible.

4 See in particular the work of Dorothy Roberts 1997 (Roberts 1997), Rickie Solinger (Solinger 2001), Laura Briggs (Briggs 2003, 2012, 2017), and Melissa Murray 2012 (Murray 2012). 
There are two particular ways that adoption shaped my own consciousness that are relevant here, and I found that many of the adoptees I have interviewed over the years have shared these perspectives. ${ }^{5}$ The first is what I refer to as an insider-outsider way of viewing social belonging. The second is a visceral understanding of what the social construction of family means. As I discussed in my first book, BirthMarks: Transracial Adoption in Contemporary America, one of the commonalities I found among the transracial adoptees I interviewed was the sense of being a perpetual interloper, of not fully belonging anywhere. This often led to the development of social practices very similar to what anthropologists call participant-observation. The origin narratives of adoptees support the understanding that we always come from somewhere and someone else. In fact, it is not just that I would have been a different person had I stayed with my birth family. A slight shuffle in the applications for adoption received in the time and place I was born might have put me into any number of different families. I always had the awareness that I could have been almost anyone. My identity feels contingent upon a broad array of social factors and a little bit of chance. In my view, this sense of simultaneously belonging both nowhere and everywhere creates the potential for a critical angle of vision on the social construction of family.

My focus on my own experience is grounded in self-reflexive ethnography. Feminist anthropologist Lila Abu-Lughod discusses the importance of positionality in conducting research in one's "own" society. She suggests that anthropologists (like herself) who are feminists and/or people of multiple races and ethnicities—-whom she refers to as "halfies"—are positioned in ways that are useful for critically considering how power shapes notions of self and "other" in ethnographic research.

The problem of studying one's own society is alleged to be the problem of gaining enough distance. Since for halfies, the Other is in certain ways the self, there is said to be the danger shared with indigenous anthropologists of identification and the easy slide into subjectivity. These worries suggest that the anthropologist is still defined as a being who must stand apart from the Other, even when he or she seeks explicitly to bridge the gap. (Abu-Lughod 1991, p. 468)

She suggests that people positioned as "outsiders" or "others" have a particular angle of vision on the ways that cultural belonging is constructed in various societies, and emphasizes the complex ways such positionality shapes the construction of academic knowledge. Her discussion focuses on ethnographers whose identities locate them as insider-outsiders in fieldwork and in the discipline of anthropology. I build on this discussion of positionality to suggest that the ways that adoptees navigate online genealogy programs are useful for thinking critically about the ways that social power relations shape the construction of families.

Anthropologists have always relied on observation and self-reflection to understand how human beings in different social and cultural contexts construct meaningful lives. Abu-Lughod emphasizes the importance of James Clifford's (Clifford 1986) famous dictum that anthropological analyses are always "partial truths," and builds on this by arguing for the "recognition that they are also positioned truths" (Abu-Lughod 1991, p. 469). In other words, people who do not easily fit into social categories of identity-like people who are biracial or immigrants or adoptees-have a particular angle of vision on the constructedness of the social system at hand. This is consistent with the feminist standpoint theory that suggests that those most subjugated by a system of power are able to see the workings of power more clearly than those who benefit from such unequal relations. Donna Haraway's notion of "situated knowledges" is a useful way of thinking about how the social positionality of adoptees in relation to definitions of family legitimacy allows us to see the relations of power at work in the literal social construction of families through adoption (Haraway 1988). Adoptees navigate family in ways that differ from non-adopted people, and this shapes the assumptions about the world we internalize.

5 I have been conducting ethnographic life history interviews with adoptees, birth mothers, and adoptive parents on and off, as part of several different research projects, since the early 1990s. 
Abu-Lughod argues for the importance of writing "ethnographies of the particular" to challenge generalizations about monolithic groups, behaviors, and cultures that often emerge from seemingly "objective" anthropological analyses.

By focusing closely on particular individuals and their changing relationships, one would necessarily subvert the most problematic connotations of culture, homogeneity, coherence, and timelessness (Abu-Lughod 1991, p. 476).

"Ethnographies of the particular" focus on how people create meaning in specific social and cultural contexts, with an emphasis on interactions between individuals and other people, communities, systems of cultural meaning, media narratives, social institutions, and laws and public policies. Those of us who stand outside the boundaries of "natural" and "normal" views of family negotiate meanings differently than those whose families adhere to hegemonic definitions of family legitimacy.

I draw on my own story not because I think my experience is "representative," but rather, because as an adoptee I make sense of my life from a particular social location and familial configuration. The specificities of my life do not represent all adoptees by any means. Yet the configuration of my family life is not random; its formation was guided by a set of rules and regulations created and maintained by governmental agencies according to social definitions of good parenting and the "best interests of children". ${ }^{6}$ The lives of adoptees differ dramatically based on an infinite number of specificities. Yet we learn to navigate meaningful lives in interaction with pervasive public narratives about adoption, family, identity, race, gender, and class. We are positioned in similar ways in relation to social definitions of identity, family, and belonging.

The origin stories I grew up hearing did not involve due dates, labor pains, and hospitals. Rather, they were about home studies and social workers, bureaucratic interviews and paperwork, and the sealing of original birth records. I always envisioned the secrets of my origins locked in a file cabinet somewhere in the California state capital. It is easy to see the presence of the state and the child welfare system in adoption narratives. This contrasts dramatically with tales of "natural" origins and blood heritage that characterizes genealogy websites. As Jerng states, "To be adopted in the modern formulation is specifically to be at the crossroads of multiple histories, the possession of which is never certain" (Jerng 2010, p. x). Indeed, the navigation of these multiple histories is central to the experience for adoptees of creating an online family tree.

I registered with an online genealogy website that was free. I had no interest in paying to explore or document my family history. Popular sites like Ancestry.com and MyHeritage.com offer an entry-level membership for free, but in order to access the research tools they provide, one must subscribe to the service. I began with a site similar to these and found it limiting, to say the least. I stumbled upon wikitree.com in my research and was pleased to discover that their "mission is to grow an accurate single family tree that connects us all and is freely available to us all". ${ }^{7}$ I created an account, including a login and password. And so, I began the documentation and exploration of my family histories.

\subsection{The Process: "Our Tree Should Be Genetic"}

I enter my name and birthdate-simple enough. Parents come next. I enter my adoptive parents' names, and search for a way to enter my birth parents too. I try entering my half-birth siblings and connecting to my birth parents through that door. It doesn't work. I have to choose either my adoptive or birth family. I explore the policies of the website, and find them unhelpful. "WikiTree only allows a person to have one mother and one father. This provides the basic structure for family trees." The only practical suggestion they offer for mediating this tension is to create two profiles for myself, connecting one to my adoptive family, and one to my birth family. I am not allowed to be one person with two sets of parents. There is a set of ontological assumptions guiding these principles that ties my identity to my parents and

6 See (Cole and Donley 1990).

https://www.wikitree.com/wiki/Help:About_WikiTree. 
those who came before them. In this formulation, I belong to either my birth or adoptive families, but there is no framework for conceptualizing the complex ways that both have shaped me.

My identity cannot be contained within this genealogy program unless I create a separate identity-the person I might have been if I had not been adopted. Yngvesson characterizes this pervasive either/or approach to discussions of adoptees' identities as the "narrative of exclusive belongings" (Yngvesson 2002, p. 8). In her analysis of transnational adoptee "roots trips", she argues that the necessary first step toward challenging this narrow framework is to explore the lived experiences of adoptees, birth parents, and adoptive parents from their own perspectives. Yngvesson (Yngvesson 2005) emphasizes the importance of exploring the ways that the life stories of adoptees, birth parents, and adoptive parents differ from each other, yet are related to and interact with each other's stories in complex ways. She argues as well for the importance of recognizing the ways that laws and public policies in the U.S. and abroad shape the lives of these three groups very differently.

Narrow constructions of nature versus nurture do not accurately represent the lived experience of family for people whose families are shaped by adoption. And thus, my discomfort with wikitree's suggestion that I create an alternate profile to represent my biological identity. What would I call this other self? My birth mother had chosen a name for me, but her mother told her not to name me because it would make it harder to let go. So "Baby Rundell" was listed on my original birth certificate. Rundell was my birth mother's legal last name, yet she had always used her step-father's last name. She did not know her father or his family well. There are no relational ties to either of these family names for me. If my birth parents had stayed together and kept me I would likely have been called Nicole Goldberg. She-an unrealized self-would have likely been raised Jewish, or at least with the knowledge that that was part of her ethnic heritage. The Latinx foster family I lived with for my first three and a half months called me Jolon. I only know that they discovered my milk allergy, and they loved me and were sad when I left. I was issued a new birth certificate listing my adoptive parents as if they had been there since my birth. None of these stories fully makes sense without the others. And none of them makes sense outside the sociopolitical context in which I was born. Each of these relationships was mediated by social institutions, laws, and public policies designed to regulate the social construction of legitimate family.

I did not set up an account representing the person I might have been had I not been adopted. As it turns out, this possibility of creating a second wikitree identity is not encouraged. The site provides detailed instructions about the importance of merging the two profiles an adoptee may create at a later date "when the issue is less sensitive". The concern is with "accurate" information for future generations, and the only reason the possibility of creating two profiles is raised is because there seems to be no simpler way within this system of conceptualizing people having more than one set of parents. The biological framework is embedded in the structure of the program. "It's important that the use of duplicates be rare and unusual. It violates basic principles of WikiTree." They provide a link to their honor code that emphasizes accuracy as paramount for the creation of a "single family tree". 8 Accuracy is defined through adherence to a definition of biological ties as real or authentic. By the regulations set forth on the website, the lives of adoptees represent a "violat(ion) of basic principles".

And thus, I am reminded, as I often am, that as an adoptee, I do not fully and completely "belong" anywhere. Wikitree's instructions continue:

This means that with adoptions, step-children, etc., a choice needs to be made. For private profiles with direct connections to living people, the family can choose which parents to include. For example, if you were adopted you can choose to enter your adoptive or biological parents as your mother and father. If your great grandfather was adopted, you should use his biological parents, if or when they are known.

8 https://www.wikitree.com/wiki/Special:Honor_Code. 
What assumptions about kinship and identity guide this distinction? The way this is framed suggests that adoptees are not "real" members of our families. As they say, in the case of living adoptees, "the family can choose which parents to include." Yet this is less straightforward than it seems. Choices only make sense in the context of the range of options available. The wikitree guidelines state:

For public profiles without connections to living people, genetic connections should prevail.

This is a choice that our community has made: our tree should be genetic.

This "choice" offered to adoptees is illusory in multiple ways. Belonging_-"real" inclusion—in the global family tree is dependent on biological connections, as per the community's decision.

People like me that were adopted in closed adoptions, have no legal access to information about biological heritage. The recovery of information about birth family history, along with searches for birth parents, has been framed as the generic answer to adoptees' questions about who we are and where (and how) we belong. The choice is not really a choice in another sense as well. We may choose to represent ourselves as part of our adoptive families on wikitree, but the instructions are clear:

Note that if the adoptive parents are used, they should be marked as Non-Biological. This will prevent incorrect DNA test connections.

The instructions are clear: no passing allowed. We are not fully part of either family, and thus, our sense of belonging is always contingent and negotiated. Yngvesson states:

The constant slippage ... between real and fictive belongings positions the adoptee and the adoptive family and, in very different ways, the birth mother in a virtual space where they are simultaneously real and not real. The adoptive family is the only de facto family of the child; yet it never becomes an unmarked (nonadoptive) family. (Yngvesson 2010, p. 13)

Adoptees' primary connections to both our family histories—our birth and adoptive parents-are effectively labeled illegitimate, and thus, we are told to mark ourselves according to these definitions of familial inclusion. If this were a dystopian novel or movie, this would be the plot device used to out the main character as not genetically desirable, as an inferior human illegitimately inhabiting elite citizenship status. ${ }^{9}$ (Gattacca 1997). Adoptees are caught between two incomplete "choices". We do not fully belong anywhere.

It is important to be clear that DNA tells a story. Ads for Ancestry.com and other genetic testing companies are blatant about this, but they discuss genetics as if it were self-evident what narratives individual genetic encryptions actually tell. Let us be clear. Genetics is a code that is anything but self-evident. We may know what a double helix looks like. We might recognize magnified images of those symbols that make up our bodies at the chromosomal level. However, what each sequence of bars means must be interpreted by experts. Someone must narrate the story. Genetics and its meanings are the micro-level story that is supposed to tell us everything we need to know about macro-level meanings of identity, family, and society. These assumptions about biogenetic belonging are embedded in social and cultural understandings of family trees, and these assumptions are intrinsic to online genealogy programs.

The emphasis on DNA in the online genealogy websites both draws on and fosters a pervasive sociopolitical narrative that biology determines "natural," and thus, "real" family ties. Social narratives about family trees, heritability, likeness, and difference reinforce notions of family as biological, natural, and thus, unchanging. The extension of this story, of course, enshrines heterosexual reproduction as natural. Reproductive justice scholar Laura Mamo explains:

Nature, or the 'facts of life,' is today biologized and geneticized. The conception narrative, which describes the origin of life, is webbed together with two other narratives: the kinship narrative, which explains the ties that make a family, and the genetic narrative, which explains individuals and their connections to the past and future. (Mamo 2007, p. 192) 
Belonging is socially narrated through familial relationships, both lived and imagined. Naturalized fictions of family and history are reproduced through the "common sense" tension between nature and nurture.

Family tree programs are not neutral, nor do they accurately represent the lived experiences of family relationships and meanings. Genealogy programs are a mainstream representation of socially legitimate family forms. Fictions of race, gender, class, sexuality, and kinship are embedded in the operating systems of free and commercial websites dedicated to family history research. Genealogy is literally encoded in a computer application program that provides a template for what counts as family. Participating requires negotiation with mainstream definitions of family legitimacy encoded in the application as biological and thus, "natural". This engagement with family history web programs reproduces macro-social definitions of family legitimacy at the individual and familial levels.

My experience as an adoptee in this online space demonstrates that definitions of family structuring the social practice of genealogy are more about recognizing socially legitimate family relationships than accurately portraying biological connections. Mamo explains:

Nothing within biology demands the nuclear family. It is a cultural and social system enforced by regulations and reinforced by legal discourse, medical practices, and cultural norms. Yet in the United States it is the nuclear family, bound by blood and legal arrangements of marriage and adoption, that represents social order, idealized kinship, and legitimate relations. (Mamo 2007, p. 5)

Family genealogy records the official story-legitimate marriages and births. In the western patriarchal model lineage is traced through legal matrimony. Children's status as legitimate citizens is dependent on their mother's marriage to a man. Critical race scholar Zanita E. Fenton explains the connections between social definitions of "legitimacy" and power relations.

Historically, illegitimacy status has assisted in gender subordination and control over female sexuality and reproduction; it has made social class standing all but pre-determined at birth; it has contributed to the maintenance of racial stratification. Indeed, illegitimate is an appropriate description for the effects of this legally and socially imposed status upon children. (Fenton 2014, p. 9)

Historically, legitimate lines of inheritance determine property transfer, class status, and social recognition, creating legal links between families and society (Coontz 2005). But what of the people who fall between these social definitions of "illegitimate" and "real" families?

\subsection{Belonging to the Tree: "Adoption Angels"}

One of the stated goals of wikitree.com is to create one family tree. "A collaborative family tree, or single family tree, is one that we all share. It's not your tree or my tree. It is our tree-a tree for the entire human family ${ }^{10}$. This sounds beautifully inclusive, and in a sense, is a deeply appealing prospect for an adoptee. But finding my place in my own family trees-the set of links necessary to connect to wikitree's view of the "entire human family" - proves problematic. How am I to connect with a shared family tree if my primary connections to it are contested in the very structure designed to document such links?

As it happens, wikitree has an answer for that! They have organized a group of genealogists known as "Adoption Angels" who volunteer to help adoptees find their biological family histories. The focus on a genetic family tree on wikitree defines biology as the path to connection with this "collaborative family tree". The "Angels" are here to help us lost souls find our "real" families and thus, the story goes, ourselves. Indeed, the project website provides links to resources for adoptees to search for birth parents outside of wikitree, as well as a set of basic guidelines pertaining to searching ${ }^{11}$.

10 https://www.wikitree.com/wiki/Help:Collaborative_Family_Tree.

11 https://www.wikitree.com/wiki/Space:Adoption_Angels_Basic_Search_Help. 
This discourse is consistent with media discussions of adoption searches-both articulate sociopolitical assumptions about genetics and identity. Reunions between adoptees and birth parents have become particularly popular media narratives in the past few decades. On television adoptees' struggles with a sense of mystery or confusion about identity, family, and history typically lead to searches for a "real self" that people assume will be revealed in reunions with birth families. Anthropologist Judith Modell comments:

Dramatized on television and reported in newspapers, reunions between long-lost kin resonate to Western literary and religious traditions. The sight of a child embracing a parent she has never known stirs the imagination, and also compels a reconsideration of love, parenthood, and relationship. (Modell 1994, p. 144)

The search is often represented as the fulcrum in life histories of adoptees-in both fictive and actual lives. Anyone familiar with daytime television talk shows or made-for-television movies could recite the typical search narrative. It is often scripted as an adoptee's quest for roots-a search for the "true" self through access to forbidden knowledge, to a previously unknown origin narrative, to a family tree, to a genetic and/or medical history, and often foremost, to the birth parents (more often, birth mother). Indeed, in much of the search literature and television discourse, searching is discussed in ways that suggest it functions as a sort of rite of passage for adoptees, a rebirth through the rewriting of the origin narrative. It is a discourse fueled by the tremendous loss that most adoptees feel in some way, but it is infused with the power of biological and genetic ways of explaining the "nature" of identity (Patton 2000).

Sociologist (and adoptee) Katarina Wegar's study of the adoption search movement in the contemporary United States found that popular search rhetoric, academic studies drawn on by search activists, and media representations of reunions among birth families focused strongly on biological sources of identity formation. In fact, she found that in psychological research on the issue, adoptees were often represented as "genealogically bewildered" and driven by "nature" to search for their biological origins. Psychology functions here as a normalizing discourse, asserting that adoptees who profess not to feel the need to search are repressing their true selves; searching is represented as an expression of a universal human need to connect and belong (Wegar 1997, p. 136).

Media stories about adoption are often framed as allegories about what shapes human identity-nature or nurture, biology or culture. Indeed, adoptees' selves are often represented in public discourse as an embodiment of the nature versus nurture tensions at the core of western assumptions regarding identity. This discourse is framed by ideas about family and identity that our ancestors, our cultures, our "bloodlines," determine who we are. While search and reunion narratives typically lean toward the nature side of the nature-nurture divide, there are also public discourses available that stress the importance of culture and environment. There is a broad range of opinions available on the relative importance of biology and culture in the development of adoptees' identities, however, little attention is accorded to the possibility that other social forces, such as public policy and social institutions, fundamentally shape the lives adoptees lead.

\section{Reducing Complexity, Denying Power}

How do these narratives get woven so deeply into our understandings of self, family, and belonging? Computer applications embedded in genealogy websites may seem to be neutral generators of family trees. However, the categories for entry are regulated by the sociopolitical assumptions about family and legitimacy embedded in social and historical constructions of genealogy. Mainstream expectations for gender, sexuality, race, and class are subtly incorporated as default categories, and biological notions of family are taken for granted as "real". We can take this analysis deeper by considering the ways that the very structure of the computer programs used on these sites reflects larger societal assumptions about legitimacy and knowledge-production.

I want to be clear that I am not critiquing the ways that genealogy websites operate. Some websites are more inclusive in regards to family form, while others are more rigid in gender representation than 
wikitree. My purpose is not to suggest changes for these programs, though I am sure that would be welcomed by many people. Rather, my aim is to explore the ways these sites organize meaning and knowledge production through a set of social and structural assumptions about what constitutes legitimate family and identity. I critique contemporary politics of reproduction and family through this exploration of genealogy websites. I view these sites not only as tools for documenting family history, but also as generators of legitimate family narratives as defined in the contemporary United States. The process of interacting with this structure reproduces hegemonic definitions of patriarchal family norms.

The logistical boundaries of computer applications available for exploring and documenting family history are regulated by the computer operating systems in which they function. New media scholar Tara McPherson's analysis of computer operating systems makes evident how the seemingly culture-free realm of codes and computations is shaped and constructed in historically and socially specific ways.

... the development of computer operating systems at midcentury installed an extreme logic of modularity that 'black-boxed' knowledge in a manner quite similar to emerging logics of racial visibility and racism (McPherson). An operating system like unix (an os that drives most of our computation, directly or indirectly) works by removing context and decreasing complexity. (McPherson 2014, p. 181)

Complexity is reduced by only allowing people to represent one set of parents. This simplicity enables the system to function, but it also limits that ways that people can represent the lived experiences of family. Adoptees are located in too complex a set of relationships-including those with the state- - to represent through this system. It is through gender specificity that the inclusion of heteronormative sex-gender identities regulates parentage. People with two moms or two dads face a similar set of obstacles in attempting to represent the lived experience of family. ${ }^{12}$

The illusion of neutrality obscures attention to gender, class, and race. The ideology of "colorblindness" is literally encoded in the logics of knowledge production guiding our everyday understandings of family history in the post World War II era. The "logic" of colorblindness as a socio-legal system is that race is "merely" a biological category with no inherent meaning, and thus, any attention to racial difference is spurious. This is accomplished by separating race from power. The absence of attention to context or complexity in the operating system unix is mirrored in the ideologies of colorblindness undergirding the U.S. legal and ideological system in the post-World War II era. Dorothy Roberts explains how the logic of legal colorblindness depends upon the absence of attention to social context and power relations. While her work focuses on African Americans, her analysis of the ways that people of color are defined through rigid, ahistorical, and homogenous definitions of race are useful for thinking critically about the social locations of all peoples defined as "non-white".

This color-blind approach to equality disregards preexisting discriminatory structures that disproportionately harm blacks even in the absence of official discriminatory motive and that may require race conscious remedies. Color blindness permits racial subordination to continue by leaving intact institutions created by centuries of official and private oppression. Viewing all government recognition of race as equally pernicious manifests an incredible blindness to current arrangements of power. (Roberts 1997, p. 366)

Roberts' incisive analysis makes clear that prohibiting all forms of racial recognition functions to reproduce and naturalize oppression by creating an illusion of neutrality and equality. Once this artifice is established, structural and institutional racism and sexism are provided a cover for maintaining and reproducing inequality.

The erasures and exclusions of this system of knowledge production-in online genealogy programs and in law and policy-are mirrored in family legitimacy as a social operating system.

12 I discuss this in depth in Sophie Has Five Mothers. 
The "blindness" or evasiveness of this ideology is its purposeful denial of power as a force shaping families differently based on their social location in relation to white heterosexual middle class family ideals. Yngvesson makes clear the connection between closed adoption laws and constructions of biological parents as the "natural real".

Without the assumption that before the adoption there is a natural real, there would be no need for adoption law to cancel the prior relation of birth parent to child, for adoptees to search for a birth parent, or for the adopted child and the adoptive family to remain forever "as if." (Yngvesson 2010, p. 15)

Maintaining the illusion of the "as if" family requires the erasure of the "natural" or "real" family the child was born into. Birth parents must be made invisible in order for the new family to narrate a sense of family legitimacy. In regards to the formation of adoptive families, the erasures are central to the reproduction of heteronormative middle class whiteness. ${ }^{13}$

My birth represented a catastrophe in the lives of my unwed teenage parents, and this is mirrored in the stigma associated with unwed pregnancy in the 1960s U.S. among white middle class teens. Getting caught having sex outside of marriage for a middle class white girl was disgraceful. ${ }^{14}$ And so my existence was erased and denied in those two families, while celebrated in my adoptive family. Adoption is part of a set of reproductive laws, policies, and practices that functioned to make extra-marital pregnancy invisible among white middle class people in the post World War II U.S. Reproductive justice scholarship is particularly useful for exploring the ways that power relations shape the social reproduction of families and the social meanings ascribed to them. A central tenet of this feminist scholarship is that laws and policies regulating reproduction and family-making have historically functioned as a means of responding to perceptions of social "crises" that must be remediated (Solinger 2005). Both out-of-wedlock pregnancy and infertility among white middle class heterosexual couples were constructed as social problems that must be made invisible by the closed adoption system in the U.S. following World War $\mathrm{II}^{15}$.

The regulation of illegitimacy has been consistently framed as a "social problem" in the United States that has been defined differently in various historical eras. Historian Rickie Solinger explains:

Reproductive politics-as-a-way-to-solve-problems reflects a belief that the social, economical, political, and moral problems that beset our country can be solved best if laws and policies and public opinions press women to reproduce or not in ways that are consistent with a particular version of the country's real needs. (Solinger 2005, p. 9)

Women of different races, classes, (dis)abilities, and sexual orientations are located differently in relation to social definitions of legitimate family and provided different levels of access to social resources necessary to achieve these socioeconomic ideals (Dill 1988). Race, gender, sexuality, class, and (dis)ability circumscribe familial legitimacy in complex and contradictory ways for mothers in different social locations. In other words, women in different social locations have access to a different range of choices (Roberts 1997). The social practice of adoption in the postwar era in the U.S. functioned to make the "deviance" of unwed pregnancy and infertility invisible. The familial complexity resulting from these social regulations does not translate into the algorithm coded into the online genealogy programs. There are no familial templates on wikitree.com that could accommodate my entire genealogy.

13 For research on sealed records see (Carp 1998) (Modell 2002).

14 See (Solinger 1992) for an in-depth discussion of the different meanings attributed to white and Black girls' unwed pregnancies prior to Roe v. Wade. The different meanings and values attributed to the mothers and their "illegitimate" babies shaped how unwed mothers were treated, and provided each population a different range of options for unwanted pregnancy.

15 In contrast, African American teens that became pregnant were discouraged from relinquishing their children for adoption because there was no "market" for their babies. 
Online genealogy programs simplify this complexity in kinship relations. These erasures are facilitated by a naturalization of kinship through the options available for documenting family relationships. This program is not just a representation of social structure, but is an operational structure that reproduces these macro-level definitions of legitimacy at the micro-level of individual family trees. What are the social functions of these versions of family history? At the most fundamental level, these stories about legitimacy function as a way of justifying the exclusion of people outside mainstream definitions of legitimate family. This approach is useful for understanding the ways that white supremacy, heteronormativity, economic inequality, and gender oppression are reproduced and reinscribed in social understandings of family, equality, and nation.

Online family tree programs operationalize patriarchal family ideology, forcing exclusions by only offering narrow options for inclusion. Not only are the categories for entry rigid, but the default settings-the social and cultural assumptions guiding this construction of family-are colorblind, heterosexual, and cis-gender. Each familial entry requires that "gender" be specified, by checking the male or female box; as I have discussed, entries only allow space for one father and one mother. By collapsing gender and sex, the program naturalizes patriarchal gender expectations for men and women, foreclosing inclusion of kin whose identities cannot be contained within these polarized categories. The rigid options function as a gatekeeping mechanism enforcing ideological constructions of heteronormative gender identities into everyday understandings of family as "common sense". ${ }^{16}$

Yet there is another important aspect of this online system for categorizing family. These programs operationalize a set of social definitions of family and identity that is so pervasive as to be largely invisible. As each person — adopted or not-interacts with these programs, their family stories are channeled through the digital template created for documenting kinship. Yet, as my experience of creating a family tree shows, the structure of this program requires a particular kind of engagement. I cannot enter more than one set of parents. I cannot have siblings from different sets of parents. I am asked to label my adoptive relationships as "non-biological" (though I do not comply). Engaging with these programs continually reconstructs and maintains U.S. patriarchal definitions of family in individual genealogical records. The messages are clear for adoptees that we do not fully belong anywhere.

Yet adoptees are not the only outsiders. This system defining family legitimacy has also been used throughout U.S. history to regulate families of color, families living in poverty, and all other kinship relations "deviating" from the patriarchal nuclear family ideal. ${ }^{17}$ Cultural Studies scholar Julia Watson emphasizes the disjuncture between western genealogical traditions and the family structures of Indigenous, enslaved, and colonized people in the United States.

If we turn to accounts of how to map genealogy for historical 'others', it becomes clear that its practices have been formed around the normative WASP subjects who first invaded and ordered America. (Watson 1996, p. 308)

Genealogical templates for "legitimate" Eurocentric family trees cannot accommodate the multiplicity of kinship forms that have characterized families of color in the U.S. ${ }^{18}$ There is a reason for this: genealogy functions as a tool of assimilation and settler colonialism in its adherence to "traditional" definitions of family. In his history of the cultural and historical shifts in practices of genealogy, Weil explains:

From the 1860s to the mid-twentieth century, racial purity, nativism, and nationalism successfully dominated the quest for pedigree and gave genealogy more contemporary

16 Ancestry.com has developed ways of representing more than one set of parents in their algorithm. One set is still designated as the default parents that appear in the family tree, but the other set can be accessed by clicking. https:/ / support.ancestry. $\mathrm{com} / \mathrm{s} /$ question/0D51500001wVrfFCAS/two-sets-of-parents. As I said earlier, genealogy website differ in the specificities of how information is accessed and represented. Yet, all of the websites still reflect and articulate ideological definitions of legitimate family.

17 Dill (1988); Glenn (1994); Gutierrez (2009); Davis (1981); O'Sullivan (2016).

18 Dill (1988). 
ideological relevance than ever before. The language of race, heredity, and later eugenics invaded the genealogical spheres, helping many white Americans describe themselves self-consciously as Anglo-Saxons and claim racial and social superiority over others. (Weil 2013, p. 6)

Genealogy as social practice shifts over time and across place, imbuing intimate relationships with societal definitions of legitimate family. In the U.S., the practice is deeply embroiled in the politics of race and reproduction. Legitimacy is a socially defined category that has been used historically to regulate kinship, belonging, and inheritance (Murray 2012). What relations of power facilitate my inclusion while denying the inclusion of others? As I have discussed, biology and culture are not the only forces shaping familial belonging. Laws and social policies regulating reproduction, property, and legitimacy have functioned differently at various historical moments.

\section{What I Found: Legitimacy and Redacted History}

Wikitree, like other genealogy websites, operationalizes hegemonic definitions of legitimate family that support and maintain ideal kinship forms. The family tree I found there was the legitimate documentation of a complex set of relationships representing the growth and development of a web of kinship ties over time. In this section, I consider the ways that the limited system I have been discussing reproduces a redacted version of family history.

My understanding of what kinship relationships mean was shaped through interaction with public narratives about roots, adoption, and family trees that I encountered in media and social interactions. Like many adoptees, I internalized a narrative that suggested that I was not a "real" member of my adoptive family. Yet, when I was twelve or so, my grandmother told me that I was more like her than any of her grandchildren. I was confused, given the societal pressure to envision biology as the touchstone for authentic family ties. I said, "How can that be? I was adopted." She didn't miss a beat. She said, "Oh, I always forget that." She provided me an alternative story about how I belong in my family. I was grafted into a family tree and nourished by its roots. I actively sought out those roots by asking my parents and grandparents about family history.

My grandmother was proud of her Union-soldier grandfather, and his older brother who had been a well-decorated Rear Admiral during the Civil War; there was even a battleship named for this Union officer, the U.S.S. Fairfax ${ }^{19}$. This was as far back in her family history as I ever heard, but she laughed as she assured me that I would be eligible to join the Daughters of the American Revolution, should I think such things mattered. Her healthy disregard of class pretensions shaped our family deeply. As an adoptee, the DAR wouldn't have me anyway; their membership status is dependent on a proven biological connection to an American "patriot". Their website states: "All lineage for the DAR must be bloodline descent." 20 Adoptees are invited to apply based on biological connections to their birth families. Of course, many adoptees do not even know who their birth parents are, due to sealed adoption records so, as I have discussed, this "choice" is often not really an option.

Years ago, when I asked her about our family history, my grandmother told me "Aunt Bird and Aunt Bell always said we were related to Lord Fairfax. But he didn't have any children". She laughed about the pretensions of caring about such things. It was apparently a bit of a family joke in my grandmother's era that we were descendants of Lord Thomas Fairfax, the only British peer residing in Colonial America, and proprietor of the vast Northern Neck Territory in what became the state of Virginia. The premise of the humor was both that ours was not a wealthy family, and that we were Northerners whose family had been in Pennsylvania for generations, and thus, certainly had never enslaved anyone. That we are a "white" family was an assumption so fundamental that to have considered otherwise was unheard of.

19 https://www.wikitree.com/wiki/Fairfax-288.

20 https://www.dar.org/im-adopted-can-i-still-become-member. 
I assumed my family had always been Northerners, until I learned my great-great grandfather and his brother were the only members of their prominent Southern slave-holding family to enlist in the Union military during the Civil War. When they left the South for good, they left those family stories behind. This discovery links me to a meticulously documented lineage available on wikitree (and many other websites), where I find histories, including kings and queens and lords and ladies and founding fathers. Once I found the details of my great great grandfather's birth, it was clear that the aunts were correct. Edwin Cary Fairfax ${ }^{21}$ was the son of a wealthy Virginia planter who enslaved human beings and used them for their labor. When the Civil War began, Edwin followed his older brother's footsteps North and enlisted in the Union Army. He proudly served under Ulysses S. Grant at Appomattox. He named his oldest daughter, my great grandmother, Nellie Grant Fairfax, ${ }^{22}$ after the daughter of General Grant. He made a modest life as a carpenter for himself and his family in Pennsylvania, and erased all connections to the history of slavery as best he could. Along with knowledge of these prominent historical figures comes a disturbing history of enslavement and oppression, that some of my ancestors were apparently eager to rebel against. What is my connection to this history? As an adoptee, I already have a troubled relationship to the very notion of genealogy—not belonging fully to either my adoptive or birth family histories. My identification leans toward the insider-outsider kin, like Edwin and his brother. Thus, I went looking for more life stories. If my own inclusion in this family tree is grounded in definitions of "legitimacy", then I have to consider whose stories may have been excluded from the family genealogy in order to maintain this illusion of social legitimacy.

The process of racializing-as-white my family genealogy depends first, on the omission of slavery in our oral family history, and second, on the legal and social fictions of genealogical legitimacy that erase enslaved ancestors from the genealogical record. Laws regulating marriage, adoption, inheritance, anti-miscegenation, labor, and property-transfer support social views of legitimate family relationships as natural, traditional, and unchanging. This construction of whiteness-intimately tied throughout U.S. history to legitimacy-obscures awareness that social categories of identity and family are shaped by power relations that shift over time, to accommodate the needs of the state. Constructions of the ideal white patriarchal family are the hinge upon which the outsiderness of "others" is defined, and thus, this public narrative of whiteness-as-purity must be critically explored.

How does one find people and stories that have been erased from history? I started looking for other ways people's lives may have been documented. It was clear that I had to move beyond the mainstream narrative represented in wikitree. I scanned documents from The Freedmen's Bureau archives, searching for family names. The property transfer records in 1813 in Alexandria, Virginia (Alexandria, Virginia Property Records 1813) provided clues to several family members' lives. On 24 December 1813, Wilson Miles Cary, ${ }^{23}$ a newly discovered grandfather seven generations back, "conveyed by deed of trust" three enslaved girls: "Sally and Charlotte two negro girls ... and Julia a mulatto girl" to his son-in-law, for "the use and benefit of his daughter." ${ }^{24}$ Were these girls Christmas gifts for his daughter? The precision in legally recording the racial identity of these three girls reflects the significance these categorizations of race had in regards to personhood and citizenship in the antebellum era. Was "Julia a mulatto girl," his daughter too? Did he send her away to remove the reminder, for his wife, that he increased their wealth by raping and impregnating enslaved women? ${ }^{25}$

Virginia law dictated that the race of the child followed the race of the mother. The children enslavers fathered with the women they raped were legally "mulatto" and enslaved like their mothers. Dorothy Roberts explains:

\footnotetext{
1 https://www.wikitree.com/wiki/Fairfax-283.

https://www.wikitree.com/wiki/Fairfax-282.

https:/ / www.wikitree.com/wiki/Cary-835.

(Alexandria, Virginia Property Records 1813). http:/ /www.freedmenscemetery.org/resources/documents/importation.shtml. See Davis (1981); Dill (1988); Collins (1991); Roberts (1997).
} 
Racism created for white slaveowners the possibility of unrestrained reproductive control. The social order established by powerful white men was founded on two inseparable ingredients: the dehumanization of Africans on the basis of race, and the control of women's sexuality and reproduction. The American legal system is rooted in this monstrous combination of racial and gender domination. One of America's first laws concerned the status of children born to slave mothers and fathered by white men: a 1662 Virginia statute made these children slaves. (Roberts 1997, p. 23)

Julia's mother is completely erased in this property transaction. Under what circumstances did a white man rape this unnamed enslaved Black woman? How did he justify his brutal behavior? He likely engaged what sociologist Patricia Hill Collins calls "controlling images" like the "Jezebel" to convince himself she wanted it (Collins 1991). Narratives of Black women's deviant sexuality have functioned as justification for rape in public discussions of race, gender, class, sexuality, and family throughout the history of the U.S. ${ }^{26}$ She is an illegitimate mother, and thus, she is erased from the historical record.

It is important to make visible the ways that sociopolitical narratives support the scaffolding of social law regulating reproduction and family, and critically explore the ways that these complex definitions of family operate through legal fictions of exclusion that are reproduced in subtle and overt ways in everyday life. In her award-winning book, The Hemingses of Monticello, historian Annette Gordon-Reed discusses family legitimacy under slavery.

Slavery simply provided families in the South with many more ways to be bizarre than in regions where it never took hold or was abandoned early on. Fathers owning sons, brothers giving away brothers as wedding gifts, sisters selling their aunts, husbands having children with their wives and then their wives' enslaved half sisters, enslaved black children and their free little white cousins, living and playing together on the same plantation-things that by every measure violate basic notions of what modern-day people think family is supposed to be about. (Gordon-Reed 2008, p. 559)

Fictions and erasures of kin function in relation to laws defining family members beyond the pale as illegitimate. Constructions of whiteness were, and are, central to social definitions of legitimate family and citizenship in the U.S., both then and now. Recognition of Julia as family challenges the sociopolitical narratives designed to make slavery appear normal and natural. Within the terms of this kinship system she cannot be acknowledged without undermining the premises undergirding the entire social structure of that time and place. And her story continues to be erased by the configuration of online genealogy programs, contributing to a whitewashed view of history.

In each era, laws, policies, and cultural understandings of legitimate family regulate belonging. "Illegitimate" children-those born outside the socially sanctioned category of legal marriage-are erased from the family tree. In 1813 in Alexandria, Virginia racial identity defined the boundaries of personhood, family, and legitimacy. Julia never became part of the official family tree because her existence would challenge ideologies of whiteness as purity, and expose the common social practice-particularly after the 1770 law banning the importation of slaves into Virginia—of white men increasing their wealth by raping women they enslaved. This reproductive practice was made invisible through erasure and denial. The transfer of Julia as property from her biological father to her biological sister was facilitated by laws defining her outside of familial relations and outside of personhood because she was "illegitimate" — born outside the sanctioned kinship system. This property transfer and its absence in the genealogical record supported white supremacy by maintaining political narratives about pure white families. It continues to narrate a redacted form of history that denies the existence of power and oppression within families and between families and the state.

26 See Davis, Dill, Collins, Roberts. 
Julia's identity and lived experience of family were shaped by societal definitions of race, sexuality, gender, legitimacy, and personhood in the U.S. in the historical moment in which she was born. Census records in the early 1800s recorded only the gender and age of enslaved people. The only trace of her existence is the documentation of a legal transaction. This property transfer is the only record of her life that I have found. Why does this story speak to me so profoundly? She is likely to have been a biological member of my adoptive family, though she was defined out of the family by social definitions of illegitimacy tied to race, gender, and capitalism. She was born outside of sanctioned relationships-under duress and oppression — and so her identity as a family member was denied at every level of meaning production.

What is my relationship to Julia? By the legal terms of family in the United States, we are not related because she has been excluded. According to genetic definitions of family, we are not family because I do not genetically belong to our family. Yet, when I consider the affiliation I feel with her based on our shared status as illegitimate, I must claim her as kin. What can we learn by looking at our different relationships to this family and its history? We were each born outside of sanctioned marriage and thus were defined as illegitimate. A legal transaction marked each of our exclusions from biological family. She was the child transferred out of the family in the antebellum era in order to ensure the illusion of wealthy white Southern families as pure and untainted by miscegenation or illegitimacy. The legal papers documenting her transfer from one family to another were recorded in the property records office, not the family Bible ${ }^{27}$. I was the child assimilated into the family through adoption in the post-World War II era, signifying a sort of redemption from the stigma of infertility for my adoptive parents and of illegitimacy for my birth parents. The legal documents detailing my actual birth are sealed by the state and unavailable except by court order. Neither of us is accurately documented in the family tree. Sociopolitical stories and legal fictions erase all traces of the legitimate transactions that defined our lives.

I wonder who Julia considered family after she was taken from her mother. Who told her stories that made her feel that she belonged somewhere? What genealogy did she claim for herself? How did she understand the meanings of race, gender, and property that regulated her life? How did she make sense of the relationships between herself and the biological relatives that enslaved and exploited her? The genealogical assumptions operating in that era would never have allowed for the inclusion of Julia in the family tree. Her absence is an effect of power. My erasure in my birth family histories is also an effect of power, as is my inclusion in the family history Julia and I share.

\section{Conclusions: Claiming Roots and Belonging}

Given the emphasis on genetic determinism in the contemporary U.S., people tend to assume that "real" genealogy is about biology and blood. For me, it is more about enculturation and stories. It is not in spite of adoption that I am interested. It is because of adoption. The insider-outsider social location of adoptees, in relation to both our birth and adoptive families, makes a connection to genealogy that is much more important to me. As Sarup explains, "the person with roots takes them for granted, while the person with no roots whatsoever is vividly aware of them, like some phantom ache in an amputated limb" (Sarup 1996, p. 4). Yet, the notion of "roots" (and what constitutes them) is profoundly shaped by social context. Power shapes constructions and understandings of kinship as surely as nature and nurture do-perhaps more, because its presence is so frequently invisible.

The tensions between exploring my birth or adoptive family history cannot be resolved. If I have to choose, I go with the people I love. The family that raised me feels real, whereas my birth parents feel like strangers. The sisters and parents I grew up with shaped my sense of self and the world in clearly identifiable ways. The stories my family told me, the ways my parents socialized my sisters

27 See Weil for a discussion of the common practice in the 19th century U.S. of documenting family births, deaths, and lineages in the family Bible. 
and I, was rooted in their own family histories. The lived experience of kinship is conveyed in stories and memories that establish connections between people to whom we are "related".

For me, the lived experience of kinship far outweighs the genetic scripts of possibility encoded in each cell of my body ${ }^{28}$. The meaning and articulation of the genetic codes my birth family passed on to me took shape and grew as part of the family that loved me and socialized me. The biggest influence of my birth parents was their absence and a lack of information about my biological family history. The relationships I have with my birth parents feel like shells of loss and unmet expectation. Social categories of parent and child did not play out according to the scripts any of us were raised with. Their children do not feel like siblings. Their identities and families do not constitute the "truth" of myself, yet my adoptive parents do not hold the sole key to my sense of self either. These are not either/or questions. I have been influenced by both families, in different ways. Nature and nurture matter, but they are not the entire story.

I read the social practice of genealogy as an operationalizing narrative enforcing normative constructions of legitimate families and identities. It shapes individual documentation of family to fit the structure of its template. These genealogical templates correspond to social and legal definitions of legitimate kinship. The structure of the family tree online programs literally enforces a normative public family story. The gaps between the genealogical template and the lived experience of family are useful for thinking about the ways that "difference" from this norm is regulated and erased, further entrenching this view of family as "natural" and "normal".

My research makes visible power inequalities governing family reproduction at macro levels by exploring the contradictions and slippages regarding family "legitimacy" in micro level online genealogical constructions of adoptees' family trees. Patriarchal family structures are naturalized and normalized in family tree programs, and the erasure of people outside the boundaries of "legitimacy" is necessary for the reproduction of socially ideal families. The nature versus nurture framework for identity limits our understandings and obscures attention to power inequalities driving the social practice of adoption.

Funding: This research was funded by a Drake University Center for the Humanities Research Grant, a Drake University College of Arts and Sciences Faculty Development Grant, and a Drake University Provost's Research Grant.

Conflicts of Interest: The author declares no conflict of interest.

\section{References}

Abu-Lughod, Lila. 1991. Writing against Culture. In Recapturing Anthropology: Working in the Present. Edited by Richard G. Fox. Sante Fe: School of American Research Press, pp. 137-54.

Alexandria, Virginia Property Records. 1813. Slave Importation Certificates in Alexandria County Records, 1790-1845. Available online: http://www.freedmenscemetery.org/resources/documents/importation.shtml (accessed on 27 August 2015).

Briggs, Laura. 2017. How All Politics Became Reproductive Politics: From Welfare Reform to Foreclosure to Trump. Berkeley, Los Angeles and London: University of California Press.

Briggs, Laura. 2003. Mother, Child, Race, Nation: The Visual Iconography of Rescue and the Politics of Transnational and Transracial Adoption. Gender \& History 15: 179-200.

Briggs, Laura. 2012. Somebody's Children: The Politics of Transracial and Transnational Adoption. Durham and London: Duke University Press.

28 This is not necessarily a common view among adoptees. In fact, many of the adoptees I have interviewed over the years have not felt a sense of belonging in their adoptive families, and thus have invested more meaning in biological views of identity and family than in cultural and relational views. Much of the public and academic discourse about adoption stays within this framework. Some people embrace biological explanations. Others believe culture and environment shape identity and family. This "commonsense" framework for understanding identity and family is rarely questioned. 
Carp, Wayne E. 1998. Family Matters: Secrecy and Disclosure in the History of Adoption. Cambridge and London: Harvard University Press.

Clifford, James. 1986. Introduction: Partial Truths. In Writing Culture: The Poetics and Politics of Ethnography. Edited by James Clifford and George E. Marcus. Berkeley, Los Angeles and London: University of California Press.

Cole, Elizabeth S., and Kathryn S. Donley. 1990. History, Values, and Placement Policy Issues in Adoption. In The Psychology of Adoption. Edited by David M. Brodzinsky and Marshall D. Schechter. New York: Oxford University Press.

Collins, Patricia Hill. 1991. Black Feminist Thought: Knowledge, Consciousness, and the Politics of Empowerment. New York: Routledge.

Coontz, Stephanie. 2005. Marriage, A History: How Love Conquered Marriage. London: Penguin Random House Books.

Cox, Susan Soon-Keum, ed. 1999. Voices from another Place: A Collection of Works from a Generation Born in Korean and Adopted to Other Countries. Saint Paul: Yeong and Yeong Press.

Cox, Susan Soon-Keum, ed. 2011. More Voices: A Collection of Works from Asian Adoptees. Seoul: Koryo Press.

Dill, Bonnie Thornton. 1988. Our Mothers' Grief: Racial Ethnic Women and the Maintenance of Families. Journal of Family History 13: 415-31. [CrossRef]

Dorow, Sara K. 2006. Transnational Adoption: A Cultural Economy of Race, Gender, and Kinship. New York: New York University Press.

Eng, David L. 2010. The Feeling of Kinship: Queer Liberalism and the Racialization of Intimacy. Durham and London: Duke University Press.

Evans, Karin. 2000. The Lost Daughters of China: Abandoned Girls, Their Journey to America and the Search for a Missing Past. New York: J.P. Tarcher/Putnam.

Fenton, Zanita E. 2014. Bastards-And the Welfare Plantation. Journal of Gender, Race and Justice 17: 9.

Glenn, Evelyn Nakano. 1994. Split Household, Small Producer, and Dual Wage Earner: An Analysis of Chinese-American Family Strategies. In Mothering: Ideology, Experience, and Agency. Edited by Evelyn Nakano Glenn, Grace Chang and Linda Rennie Forcey. New York and London: Routledge.

Gordon-Reed, Annette. 2008. The Hemingses of Monticello: An American Family. New York: W. Norton \& Company. Gutierrez, Elena R. 2009. Fertile Matters: The Politics of Mexican Reproduction. Austin: University of Texas Press.

Haley, Alex. 1976. Roots. Garden City: Doubleday.

Haraway, Donna. 1988. Situated Knowledges: The Science Question in Feminism and the Privilege of Partial Perspective. Feminist Studies. 14: 575-99. [CrossRef]

Haslanger, Sally, and Charlotte Witt, eds. 2005. Adoption Matters: Philosophical and Feminist Essays. Ithaca and London: Cornell University Press.

Ito, Susan, and Tina Cervin, eds. 1999. A Ghost at Heart's Edge: Stories and Poems of Adoption. Berkeley: North Atlantic Books.

Jerng, Mark C. 2010. Claiming Others: Transracial Adoption and National Belonging. Minneapolis: University of Minnesota Press.

Kim, Eleana. 2005. Wedding Citizenship and Culture: Korean Adoptees and the Global Family of Korea. In Cultures of Transnational Adoption. Edited by Volkman Toby Alice. Durham and London: Duke University Press.

Kim, Eleana. 2010. Adopted Territory: Transnational Adoption and the Politics of Belonging. Durham and London: Duke University Press.

Lifton, Betty Jean. 1988. Lost and Found: The Adoption Experience. New York: Dial Press.

McPherson, Tara. 2014. Designing for Difference. Differences: A Journal of Feminist Studies 25: 177-88. [CrossRef]

Mamo, Laura. 2007. Queering Reproduction: Achieving Pregnancy in the Age of Technoscience. Durham: Duke University Press.

Modell, Judith S. 1994. Kinship with Strangers: Adoption and Interpretations of Kinship in American Culture. Berkeley: University of California Press.

Modell, Judith S. 2002. A Sealed and Secret Kinship: The Culture of Policies and Practices in American Adoption. New York and Oxford: Berghahn Books.

Murray, Melissa. 2012. What's So New about the New Illegitimacy? The American University Journal of Gender, Social Policy \& the Law 20: 387-436.

Nelson, Kim Park. 2009. Mapping Multiple Histories of Korean American Transnational Adoption. In Contemporary Asian America: A Multidisciplinary Reader. New York: NYU Press.

Gattacca. Directed by Andrew Niccol. Culver City: Columbia Pictures, 1997. 
O'Sullivan, Meg Devlin. 2016. More Destruction to These Family Ties: Native American Women, Child Welfare, and the Solution of Sovereignty. Journal of Family History 41: 19-38. [CrossRef]

Oh, Arissa H. 2012. From War Waif to Ideal Immigrant: The Cold War Transformation of the Korean Orphan. Journal of American Ethnic History 4: 34-55. [CrossRef]

Patton, Sandra. 2000. BirthMarks: Transracial Adoption in Contemporary America. New York and London: New York University Press.

Patton-Imani, Sandra. 2012. Orphan Sunday: Narratives of Salvation in Transnational Adoption. Dialog: A Journal of Theology 51: 294-304. [CrossRef]

Patton-Imani, Sandra. 2014. Someone's Roots: Gender, Rape, and Racialization in Korean American Adoption Narratives. In Race in Transnational and Transracial Adoption. Edited by Vilna Bashi Treitler. London: Palgrave University Press.

Patton-Imani, Sandra. 2019. Sophie Has Five Mothers: Race, Queerness, and Family-Making. New York: New York University Press.

Richards, Sarah. 2012. What the Map Cuts up the Story Cuts Across': Narratives of Belonging in Intercountry Adoption. Adoption \& Fostering 36: 104-11.

Roberts, Dorothy. 1997. Killing the Black Body: Race, Reproduction, and the Meaning of Liberty. New York: Pantheon Books.

Sants, Harold J. 1964. Genealogical bewilderment in children with substitute parents. British Journal of Medical Psychology 37: 133. [CrossRef] [PubMed]

Sarup, Madan. 1996. Identity, Culture, and the Postmodern World. Athens: The University of Georgia Press.

Solinger, Rickie. 1992. Wake up Little Susie: Single Pregnancy and Race before Roe v. Wade. New York: Routledge.

Solinger, Rickie. 2001. Beggars and Choosers: How the Politics of Choice Shapes Adoption, Abortion, and Welfare in the United States. New York: Hill and Wang.

Solinger, Rickie. 2005. Pregnancy and Power: A Short History of Reproductive Politics in America. New York: New York University Press.

Thorne, Barrie, and Marilyn Yalom, eds. 1982. Rethinking the Family: Some Feminist Questions. Boston: Northeastern University Press.

Trenka, Jane Jeong, Julia Chinyere Oparaha, and Sun Yung Shin, eds. 2006. Outsiders Within: Writing on Transracial Adoption. Boston: South End Press.

Volkman, Toby Alice, ed. 2005. Cultures of Transnational Adoption. Durham and London: Duke University Press.

Watson, Julia. 1996. Ordering the Family: Genealogy as Autobiographical Pedigree. In Getting a Life: Everyday Uses of Autobiography. Edited by Julia Watson and Sidonie Smith. Minnesota: University of Minnesota Press.

Wegar, Katarina. 1997. Adoption, Identity, and Kinship: The Debate over Sealed Birth Records. New Haven and London: Yale University Press.

Weil, Francois. 2013. Family Trees: A History of Genealogy in America. Cambridge: Harvard University Press, vol. 107, p. 247.

Yngvesson, Barbara. 2002. Placing the "gift child" in transnational adoption. Law and Society Review 36: $227-56$. [CrossRef]

Yngvesson, Barbara. 2005. Going 'Home': Adoption, Loss of Bearings, and the Mythology of Roots. In Cultures of Transnational Adoption. Edited by Volkman Toby Alice. Durham and London: Duke University Press.

Yngvesson, Barbara. 2010. Belonging in an Adopted World: Race, Identity, and Transnational Adoption. Chicago: University of Chicago Press, vol. 36, pp. 137-39.

(C) 2018 by the author. Licensee MDPI, Basel, Switzerland. This article is an open access article distributed under the terms and conditions of the Creative Commons Attribution (CC BY) license (http://creativecommons.org/licenses/by/4.0/). 